\title{
Effects of suspended mussel culture (Mytilus spp.) on sedimentation, benthic respiration and sediment nutrient dynamics in a coastal bay
}

\author{
A. Hatcher*, J. Grant, B. Schofield \\ Dalhousie University, Dept of Oceanography, Halifax, Nova Scotia, Canada B3H 4J1
}

\begin{abstract}
Many studies have shown that the primary effect of shellfish culture on nearshore marine systems is enhanced sedimentation. This study was designed to measure the effects of this enhanced sedimentation on the respiration and nutrient fluxes of the benthic community and the coupling between the pelagic and benthic systems at a mussel culture site (Mytilus edulis and $M$. trossulus) in Upper South Cove, Nova Scotia, Canada. There was a significant association between chlorophyll in the water column and sedimentation rate in Upper South Cove over the study year, 1990, particularly under the mussel lines, but the majority of the particulate carbon and nitrogen which fell to the bottom was not incorporated into the sediments. Suspended mussel culture had little impact on sediment phosphorus dynamics. The largest response of the sediment community to suspended mussel culture was ammonium release, which was higher under the mussel lines at all times of the year. Over the year, the sediments of the reference site were a net sink for total dissolved nitrogen, while the sediments under the mussel line were a source.
\end{abstract}

KEY WORDS: Sediment - Respiration · Nutrient flux · Aquaculture

\section{INTRODUCTION}

Aquaculture operations in nearshore bays have been growing world-wide. The reasons for this growth include the depletion of wild stocks, the rapid growth of profitable species in protected nearshore systems and the ease of servicing containment facilities and harvesting. It has been demonstrated by many authors that organic input due to finfish culture has a substantial impact on the benthos which includes carbon and nitrogen accumulation in sediments (Hall et al. 1990, 1992), dominance of opportunistic polychaete assemblages and lower macrofaunal biomass (Hargrave et al. 1993), enhanced sediment metabolism and sulphate reduction (Holmer \& Kristensen 1992) and high ammonium efflux and sulphide accumulation (Hargrave et al. 1993). Several recent studies have addressed the environmental impacts of bivalve shell-

\footnotetext{
- Present address: CFRAMP Resource Assessment Unit, Tyrell St., Kingston, St. Vincent, West Indies
}

fish culture (Kasper et al. 1985, Baudinet et al. 1990), and have found them less dramatic than with finfish culture. Sediments at finfish culture sites receive significant organic input as fish faeces and uneaten food. Bivalves feed on natural phytoplankton, and organic input to the sediments is largely composed of rapidly sedimenting biodeposits such as faeces and pseudofaeces.

The purpose of this study was to examine the impacts of suspended mussel culture on aspects of benthic nutrient cycling in a nearshore bay. In nearshore marine systems, sediments are active in the process of nutrient regeneration from organic material with a net flux of inorganic nutrients to the water column (Klump \& Martens 1981, Lomstein et al. 1989, Rizzo 1990). However, there are large reported ranges of fluxes for many of the nutrients both within the same study site and among sites. Thus, impacts of activities such as shellfish culture can be difficult to quantify.

As well as high variability, our understanding of sediment nutrient dynamics has been hampered by the lack of seasonal data collected simultaneously on a 
suite of nutrients, as the dissolved organic fluxes are often ignored (Koop et al. 1990). For these reasons, we monitored components of sediment metabolism simultaneously, paying special attention to the role of dissolved organic nitrogen and phosphorus. We examined the coupling between water column properties and sediment metabolism at a mussel culture site and a nearby reference site over the period January to November 1990, paying particular attention to the icecovered winter period, about which little is known. This allowed us to develop a comprehensive seasonal picture of sediment fluxes, water column chlorophyll concentrations and sedimentation of particulate organic matter to the benthos.

\section{METHODS}

Sampling sites. Upper South Cove is an enclosed bay on the Atlantic Coast of Nova Scotia, Canada, within a larger bay, Lunenburg Bay (Fig. 1). At the Corkum Island mussel farm, mussels are cultured on longlines in the upper $3 \mathrm{~m}$ of the water column at a density of approximately 400 mussels $\mathrm{m}^{-2}$. The farm produces both Mytilus edulis and $M$. trossulus and has been in operation since the late 1970s. The cove is relatively enclosed, confined at one end by a continuous causeway, and at the other by a restricted opening through which the only tidal exchange occurs. The tidal range is 1 to $2 \mathrm{~m}$. For this study, 2 sites were chosen. Both sites are in the deep section of Upper

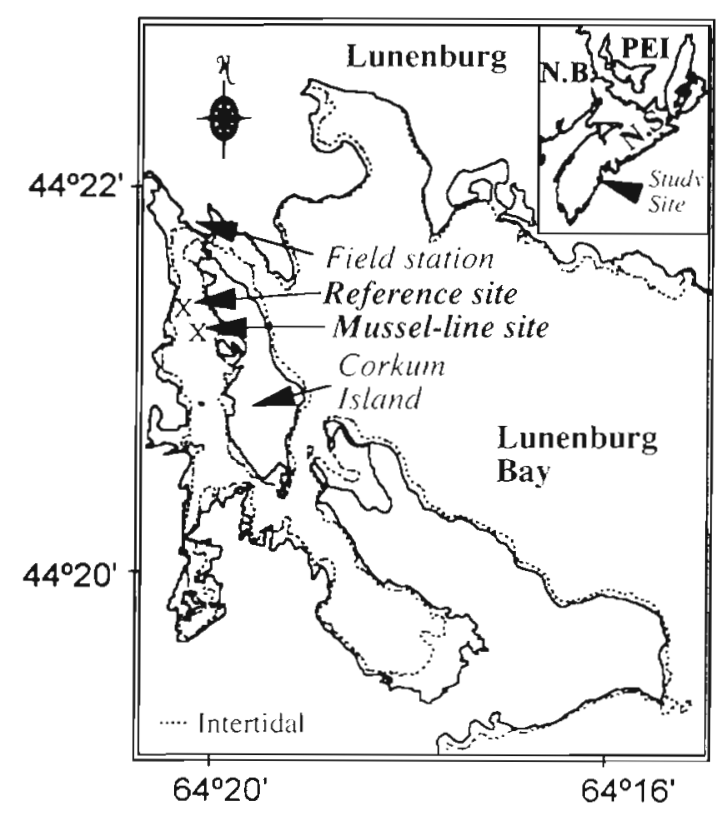

Fig. 1 Upper South Cove, Nova Scotia, Canada, and the location of the study sites
South Cove in a depositional basin ( $7 \mathrm{~m}$ depth), located about $30 \mathrm{~m}$ apart. The mussel-line site is directly under a commercial mussel-line array which covers an area of approximately $4000 \mathrm{~m}^{2}$. The reference site is in an area of similar depth and sediment type (mud) located parallel to the mussel-line on the tidal flow axis.

Sediment traps. Sedimentation was measured in acrylic tubes $(6 \mathrm{~cm}$ i.d., $60 \mathrm{~cm}$ long) closed at the bottom with a rubber stopper. Eight tubes were secured in a weighted plastic box which was set on the sediment surface (Novitsky 1990). The traps were deployed between April 20, 1989 and April 20, 1990 for periods which averaged $2 \mathrm{wk}$. Within several hours of collection, trap contents, including all suspended particles, were filtered onto Whatman GF/F filters which were dried and weighed. Carbon and nitrogen analyses were performed on $10 \mathrm{ml}$ subsamples of trap contents filtered onto silver filters $(0.8 \mu \mathrm{m}$ Hytrex membranes; Osmonics Inc., Minnetonka, MN, USA) with a Perkin Elmer model 185B CHN analyser. Further details of sediment traps can be found in Novitsky (1990).

Field collection of cores. Ten sampling trips were conducted in 1990 (Table 1), During each trip, sites were sampled randomly within a $5 \mathrm{~m}$ radius of a site marker. All sediment samples were collected by divers using SCUBA. During the winter period (December to March) access holes were cut through the ice with a chain saw. Three types of cores were used. The first type, the 'flux' core $(12 \mathrm{~cm}$ i.d., $30.5 \mathrm{~cm}$ long), was collected by gently pushing the open-ended PVC tube into the sediment, to preserve the sediment horizons. The sediment collected was approximately $10 \mathrm{~cm}$ thick. When in place, a tight-fitting stopper was installed on the bottom, by sliding it down and under the core. A second valved stopper was installed on the top end of the core with the valve open. After placement of the bottom stopper, the valve on the top stopper was closed and the core was withdrawn from the surrounding sediments. Cores were kept in the dark, at collection temperature and returned to the field lab within 30 min for incubation. Because the incubation chamber could only accommodate 5 cores, 4 replicate sediment cores and 1 water-only core from each site were analysed on each day of the $2 \mathrm{~d}$ trip.

The second type of core, the 'surface skimmer' core $(6.5 \mathrm{~cm}$ i.d., $15 \mathrm{~cm}$ long), was used to measure the composition of recently-deposited sediment. These cores were passed along the surface sediment by the diver (to a depth of approximately $2 \mathrm{~cm}$ ), and stoppers were installed at both ends. During each day of each sampling trip, 4 replicate 'flux' cores and 3 replicate 'surface skimmer' cores were deployed at each site.

The third type of core, the 'profile' core, was collected only on November 15 . These cores were $6.5 \mathrm{~cm}$ 
Table 1. Sampling trips to Upper South Cove in 1990; on each sampling trip, 4 replicate 'flux' cores were collected at each site

\begin{tabular}{|llc|}
\hline Season & \multicolumn{1}{c}{ Dates } & Julian day \\
\hline Winter & January 25-26 & 25 \\
& February 8-9 & 39 \\
& February 22-23 & 53 \\
Spring & March 8-9 & 67 \\
& April 19-20 & 109 \\
Summer & May 3-4 & 123 \\
& June 28-29 & 179 \\
Autumn & August 9-10 & 221 \\
& November 1-2 & 305 \\
& November 15-16 & 319 \\
\hline
\end{tabular}

i.d. and $30 \mathrm{~cm}$ long, and were pushed into the sediment by the diver, stoppered and carefully extracted to preserve sediment horizons. The extruded horizons of 0 to $1 \mathrm{~cm}, 9$ to $10 \mathrm{~cm}$ and 19 to $20 \mathrm{~cm}$ were isolated and frozen.

All sampled sediments were frozen immediately and transported back to the laboratory. After thawing, sediments were dried at $60^{\circ} \mathrm{C}$ until a constant weight was reached ( $3 \mathrm{~d})$, and ground to a fine powder with a mortar and pestle. The powdered samples were then analysed in triplicate for carbon and nitrogen concentration using a Perkin Elmer 2400 Elemental Analyser. In preliminary trials, no significant difference was noted in the carbon concentration of samples which were acid-leached and those which were not (data not shown). Therefore, results are reported as 'total carbon', but it is expected that total is largely organic carbon. In the deep cores taken in August, water content was estimated by using the weight differences before and after drying. These data were used to estimate porosity (Holme \& McIntyre 1984), with a correction for salt content and assuming a density of solids of $2.65 \mathrm{~g} \mathrm{~cm}^{-3}$.

Processing of 'flux' cores. Upon return to the field laboratory, the 'flux' cores were fitted with end caps which allowed removal and replacement of supernatant water. This was necessary to allow subsampling at the beginning and end of incubations for nutrient analyses. These end caps were also fitted with magnetically driven impellors. The cores, which were 33\% sediment volume and $67 \%$ supernatant water, were then placed in a controlled-temperature incubation chamber at the in situ temperature. Because the water temperature was often $<0^{\circ} \mathrm{C}$ in the winter, the incubation chamber was cooled with antifreeze [Mastercraft Plumbing Antifreeze $\left(-40^{\circ} \mathrm{C}\right.$, no. 63-9927-2)]. When the cores were placed in the incubation chamber, subsamples of supernatant water were removed for analysis of initial nutrient concentration. Water from the site of core collection was used to replace the $250 \mathrm{ml}$ removed. Each core tube was fitted with a pre- calibrated Orion oxygen electrode and connected to a Toshiba lap-top computer via an Orion switchbox (model 607) and an Orion pH meter (model SA720). Oxygen was monitored regularly in the supernatant water of all cores, while the water was slowly circulated from above with a magnetically driven impellor. The impelior was coupled to a magnet on the outside of the endcap which was driven by a stream of compressed air at a speed of approximately $80 \mathrm{rpm}$. Stirring did not physically disturb the sediment surface. Incubations were terminated when the oxygen consumption rate was steady and linear (usually after 2 to $5 \mathrm{~h}$ ), and the oxygen concentration was approximately $80 \%$ of the initial values (which were all close to saturation). A core containing bottom water only was used to control for respiration and nutrient fluxes in overlying water as well as consumption by the oxygen electrode. Oxygen consumption due to the probe and the overlying water could be as high as $10 \%$ of the sediment respiration. Following incubations, the core contents were sieved through $500 \mu \mathrm{m}$ mesh and retained material was preserved in $4 \%$ buffered formalin-rose bengal. Fauna were then sorted to species in separate vials. Individual tissue weights were determined after drying vial contents at $60^{\circ} \mathrm{C}$ overnight and weighing. The weights were not corrected for salt content or loss of weight due to formalin dissolution. Bivalves were removed from their shells prior to drying. Gastropods were too small to dissect, so tissue weight was calculated as $10 \%$ of total dry weight, based on measurements of local Littorina spp.

Fluxes of $\mathrm{NH}_{4}{ }^{+}, \mathrm{NO}_{3}{ }^{-}, \mathrm{NO}_{2}{ }^{-}, \mathrm{PO}_{4}{ }^{3-}, \mathrm{DON}$ and DOP were calculated as the change in concentration in the supernatant water divided by the incubation time, and oxygen consumption rate was calculated as the slope of the decline in oxygen concentration. This rate was calculated by ignoring the first 10 to $20 \mathrm{~min}$ of observation, when unsteady declines were often noted. The calculated rates were based on regressions with $r^{2}$ values greater than 0.95 .

All water samples were analysed for $\mathrm{NH}_{4}{ }^{+}, \mathrm{NO}_{3}{ }^{-}$, $\mathrm{NO}_{2}{ }^{-}$and $\mathrm{PO}_{4}{ }^{3-}$ using standard techniques as in Parsons et al. (1984). Water samples for these analyses were taken from the $250 \mathrm{ml}$ initial and final samples of water overlying the sediments. Analyses for $\mathrm{NH}_{4}{ }^{+}$, $\mathrm{NO}_{3}{ }^{-}, \mathrm{NO}_{2}{ }^{-}$and $\mathrm{PO}_{4}{ }^{3-}$ were performed with a precision on triplicate samples of greater than $95 \%$. DOP was analysed using the method of Solarzano \& Sharp (1980a). Precision ranged from 92 to $100 \%$ for the recovery of the standard potassium dihydrogen orthophosphate. DON was analysed using a modification of the method of Solarzano \& Sharp (1980b). The modification entailed separate $\mathrm{pH}$ estimation and individual buffering for each step of the oxidation, rehydration, acidification steps in the DON analyses, because the 
buffering capacity of the water varied considerably from sample to sample. Precision ranged from 92 to $103 \%$ for recovery of the urea standard.

Water column characteristics and chl a estimation. A moored instrument array placed $3.5 \mathrm{~m}$ above the sediment surface at the reference site provided estimates of temperature, current velocity, salinity and concentrations of chlorophyll a ( $\mathrm{chl} a)$ and suspended particulate material. The array consisted of a Sea Tech fluorometer, thermister, transmissometer $(10 \mathrm{~cm}$ path length), a Marsh-McBurney electromagnetic current meter, and a conductivity cell connected to an Applied Microsystems ECM-12 data logger. Hourly measurements of water temperature, conductivity, transmittance and fluorescence were obtained continuously from the moored instruments except for breaks of several hours every 2 wk when the batteries were changed and data downloaded.

Chl a concentrations were estimated from the fluorometer voltage data, which was converted into units of chl $a$ with equations derived from laboratory calibrations using cultures of Chaetocerus mulleri, Thalassiosira weissflogii and $T$. isochrysis (galbana). Although the most accurate way of calibrating in situ fluorescence is with samples taken in situ and measured spectrophotometrically (Strass 1990), this method was not used in Upper South Cove because the range of concentrations was not sufficient to generate a reliable regression. The lab cultures were chosen because they closely resemble the species present in the cove. On several occasions the calculated concentrations were compared to chl a concentrations measured in water samples taken adjacent to the moored instrument, and the values always agreed within $10 \%$ of each other (Emerson et al. 1994).

Benthic microalgal production. Small quantities of surface sediment were placed in replicate light and dark BOD bottles filled with filtered seawater (Whatman GFC filters) and incubated just off the bottom for $24 \mathrm{~h}$ periods ( $\mathrm{n}=11$ incubations, February to November). Initial and final oxygen concentration was determined with either oxygen electrodes or Winkler titrations.

Data analysis. Data was analysed using SYSTAT (Wilkinson et al. 1992). To explore the relationship between water column chl a concentration and sedimentation rate, it was assumed that sedimentation measured in traps during the period of May 1, 1989, to November 20, 1989, applied to the same period in 1990. This was necessary because the data collection periods for the 2 variables were not the same, with the overlap spanning only the period of ice cover and the following 2 mo (January 1 to May 1, 1990).

To determine whether the carbon and nitrogen concentrations in sediments from the 'surface skimmer' cores differed among sites or whether the seasonal changes were significant, a 2-factor (site and season) ANOVA was used. Between-site differences were examined using an a posteriori Tukey test. Homogeneity of variances were tested using Bartlett's test before all ANOVAs.

The relationships between sediment respiration rate and other variables were explored using forward stepwise regression. Variables were entered into the model beginning with the most significant predictor until no more could significantly improve the fit. The minimum tolerance for entry into the model was 0.10 , and the alpha values for entry and removal were set at 0.15 . The models which were generated at one site using these criteria were then tested at the second site as a multiple regression model (see Tables $4 \& 6$ ).

\section{RESULTS}

\section{Water column characteristics}

Water temperatures ranged from a seasonal daily mean of $0.3^{\circ} \mathrm{C}$ in winter to a summer mean of $15.0^{\circ} \mathrm{C}$ (Fig. 2a). Salinities at the reference site ranged from 29.72 to $30.74 \%$ during the study. Currents at the
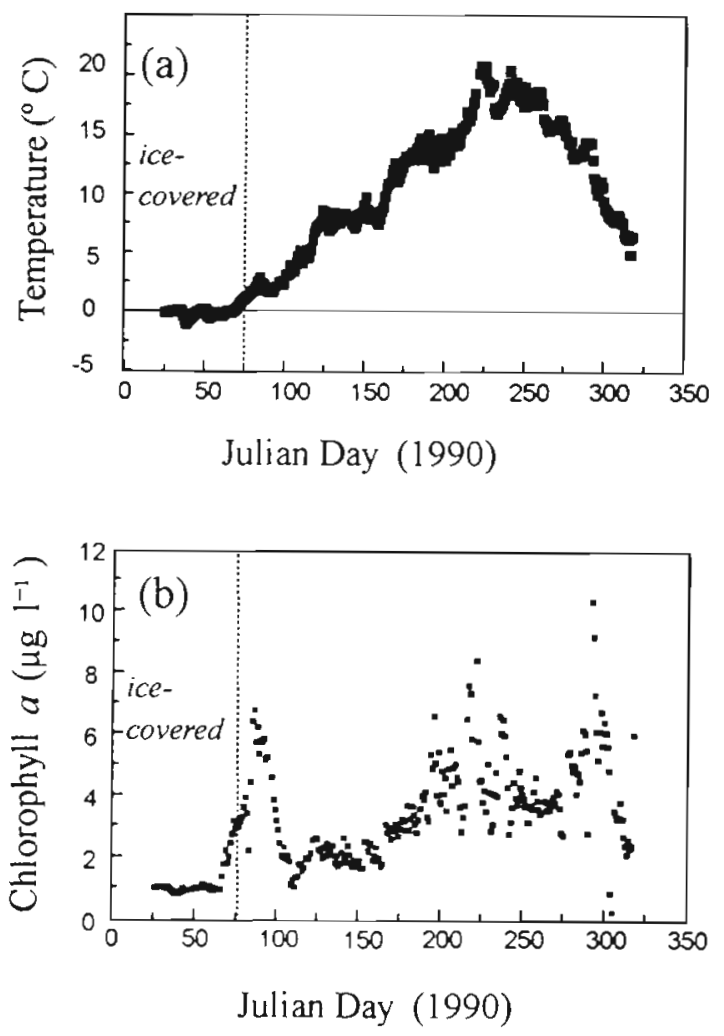

Fig. 2. (a) Water temperature and (b) chlorophyll a concentration at reference site in Upper South Cove in 1990 
reference site ranged from 4 to $7 \mathrm{~cm} \mathrm{~s}^{-1}$, but peaks of up to $20 \mathrm{~cm} \mathrm{~s}^{-1}$ were measured. Strongest currents usually showed a tidal prism, in the directions of $80^{\circ}$ and $260^{\circ}$ (as demonstrated in Fig 3). The concentrations of suspended particulate matter ranged from 5 to $20 \mathrm{mg} \mathrm{l}^{-1}$, with low values in winter and high in late fall. A representative plot of hourly current velocities and directions and corresponding concentrations of suspended particulate material for 5.6 tides between June 28 and July 1, 1990, is shown in Fig. 3. Using these data, a rough calculation of tidal flux across the bottom at the reference site can be made. If current velocities and concentrations of suspended particulate material at $1 \mathrm{~m}$ above the sediment surface are similar to the measurements at $3.5 \mathrm{~m}$ above, tidal flux between June 28 and July 1 ranged from $613 \mathrm{~g}$ dry wt $\mathrm{m}^{-2} \mathrm{~h}^{-1}$ from the SW $\left(0\right.$ to $\left.90^{\circ}\right)$ to $2374 \mathrm{~g}$ dry wt $\mathrm{m}^{-2} \mathrm{~h}^{-1}$ from the NE $\left(180\right.$ to $\left.270^{\circ}\right)$ in the water up to $1 \mathrm{~m}$ above the sediment surface.

A distinct phytoplankton bloom was recorded in March, while Upper South Cove was still ice-covered. During the bloom, chl a concentrations reached $6 \mu \mathrm{g}$

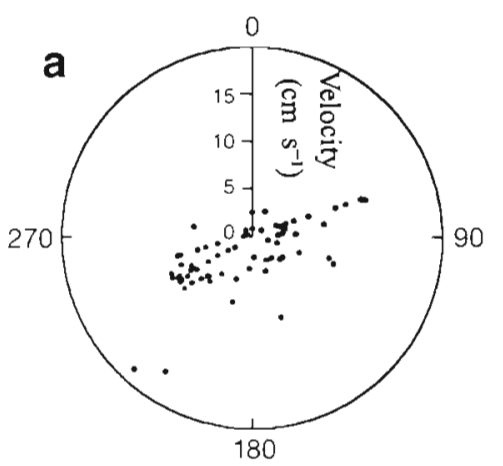

Current direction (degrees)

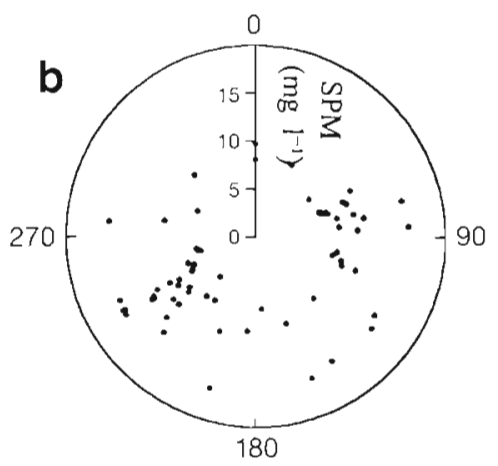

Current direction (degrees)

Fig. 3. (a) Hourly current velocity plotted against current direction and (b) corresponding concentrations of suspended particulate matter (mg dry wt $\mathrm{l}^{-1}$ ) plotted against current direction from continuously recording instruments placed at $3.5 \mathrm{~m}$ above the sediment surface at the reference site in Upper South Cove; the hourly data were collected over 5.6 tidal cycles between June 28 and July 1, 1990 $\mathrm{l}^{-1}$, and dropped rapidly to less than $1 \mu \mathrm{g} \mathrm{l}^{-1}$ in April, when ice was breaking up. A steady increase in chl a concentration was then measured until early July. The summer period, from July to September, was marked by high and variable chl a concentrations, with a sharp decline measured from October to November (Fig. 2b).

Ambient concentrations of nutrients in the water column immediately above the sediment surface were similar at the 2 sites. $\mathrm{NH}_{4}{ }^{+}$concentrations ranged from $2.0 \mu \mathrm{M}$ in the winter to $4.9 \mu \mathrm{M}$ in the summer. $\mathrm{NO}_{3}^{-}$ and DON showed the reverse seasonal pattern with lows in autumn $\left(0.4 \mu \mathrm{M}\right.$ for $\mathrm{NO}_{3}{ }^{-}$and $4.2 \mu \mathrm{M}$ for $\left.\mathrm{DON}\right)$ and highs in winter $\left(2.5 \mu \mathrm{M}\right.$ for $\mathrm{NO}_{3}{ }^{-}$and $16.6 \mu \mathrm{M}$ for DON). Nitrite $\left(\mathrm{NO}_{2}^{-}\right)$ranged from $0.1 \mu \mathrm{M}$ in the summer to $0.2 \mu \mathrm{M}$ in the winter; $\mathrm{PO}_{4}{ }^{3-}$ from $0.6 \mu \mathrm{M}$ in the spring to 1.7 in summer and DOP from $0.1 \mu \mathrm{M}$ in winter to 1.7 in the autumn (data not shown).

\section{Sedimentation rate}

Sedimentation rates as measured in the sediment traps were low in winter and high in late summer and autumn, but were always significantly higher by at least a factor of 2 at the mussel-line site than the reference site, with the greatest difference shown during the autumn (Days 280-320 in Fig. 4). Lowest variability in sedimentation rate was measured during the winter at both sites. When the sedimentation rates were grouped according to season, there were significant between-site differences using $t$-tests within each season on log-transformed data (winter $t=20.4$, spring $t=4.5$, summer $t=9.5$, autumn $t=7.7, \mathrm{p}<0.001$ in all seasons). 2-way ANOVAs could not be used because of heteroscedastic variances among seasons.

The carbon and nitrogen concentrations of sediment trap contents were not measured over an annual cycle,

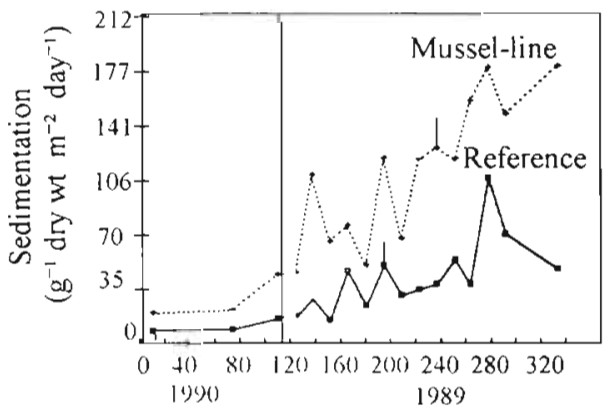

Julian Day (1990 and 1989)

Fig. 4. Sedimentation rate, as measured in sediment traps, at 2 sites in Upper South Cove during 1989 and 1990. Note: the data from 1990 has been transposed to the beginning of the graph to allow a progression on the independent axis from Day 1 (January 1). Vertical lines represent the maximum standard error within a sampling period at each site 
but only during the period of April 20 until August 25, 1989. During that period of late spring and summer, the carbon concentration of sediment trap contents ranged from 0.73 to $18.87 \%$ (of dry wt) at the reference site and 1.39 to $15.88 \%$ at the mussel-line site. The molar $\mathrm{C}: \mathrm{N}$ ratios of the sediment trap material ranged from 2.3 to 22.2 at the reference site and 4.6 to 10.75 at the mussel-line site (J. A. Novitsky unpubl. data). Because of the high variability there was not a significant site difference as measured by $t$-tests (carbon; $t=-1.13, \mathrm{p}=0.27 ; \mathrm{C}: \mathrm{N}_{i} t=1.04, \mathrm{p}=0.32$ ).

At both sites, a distance-weighted least-squares fitted line indicated a linear relationship between chl a concentration in the water column at the reference site and sedimentation rate at both sites up to a chl a concentration of approximately $4.0 \mathrm{\mu g} \mathrm{l}^{-1}$ (Fig. 5). A linear regression model was tested at each site to examine the relationship between chl a concentration at the reference site and sedimentation rate at both sites when concentrations of chl a were less than $4.0 \mathrm{\mu g} \mathrm{l}^{-1}$. As is evident in Fig. 5, the relationship is stronger at the mussel-line site $\left(r^{2}=0.746\right)$ with a larger slope (54.45) than at the reference site $\left(\mathrm{r}^{2}=0.669 ;\right.$ slope $\left.=25.59\right)$.

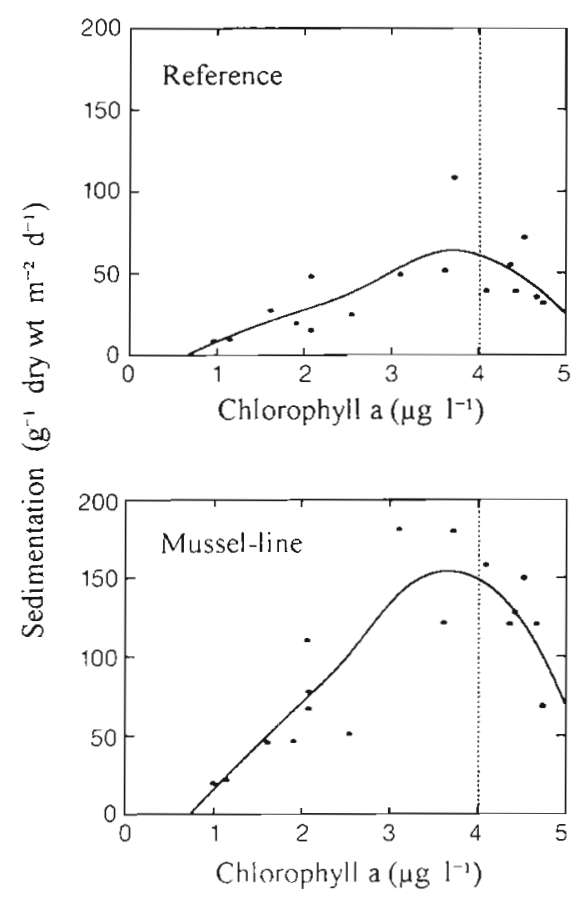

Fig. 5. Sedimentation rate, as measured in sediment traps, at 2 sites in Upper South Cove during 1989 and 1990 plotted against chlorophyll a concentrations in the water column at the reference site during 1990 which is averaged over periods corresponding to the sediment trap deployments; lines are plotted as distance-weighted least squares in SYSTAT; dashed vertical lines represent a chlorophyll concentration of $4.0 \mathrm{\mu g} \mathrm{l}^{-1}$ below which a linear model was tested to examine the relationship (see text)

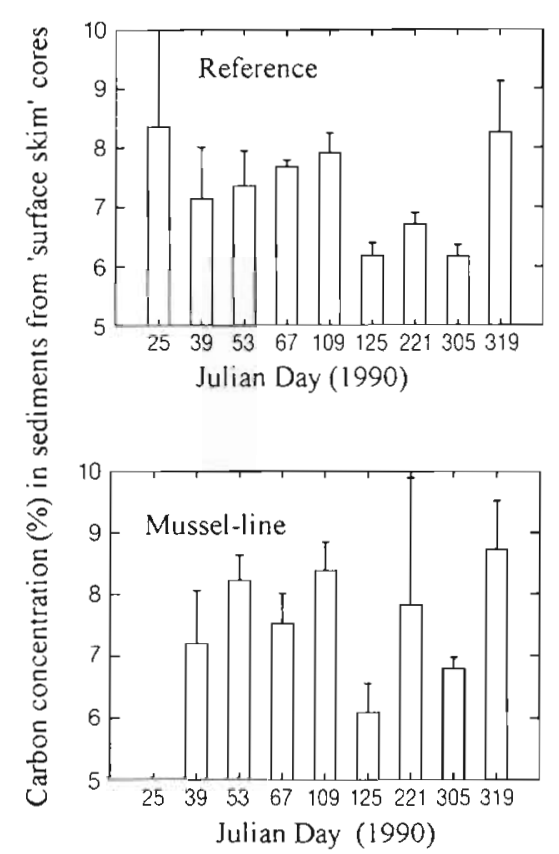

Fig. 6. Carbon concentration of sediments collected in 'surface skimmer' cores during 1990. Each mean is based on 4 replicate cores, and standard errors are plotted as vertical lines

\section{Bulk carbon and nitrogen content of sediments}

The carbon concentration in sediments from the 'surface skim' cores showed a similar seasonal pattern at the reference site and the mussel-line site, with the largest difference noted in August (Fig. 6). Highest carbon concentrations were measured in November (Day 320) and lowest in May (Day 123). The mean annual carbon concentration of surface sediments sampled in the 'surface skim' cores was $7.13 \%$ $(\mathrm{SE}=0.23, \mathrm{n}=44)$ at the reference site and $7.50 \%$ ( $\mathrm{SE}=0.19, \mathrm{n}=39$ ) at the mussel-line site. Because of the high variability, there was no significant difference due to site or season [2-way ANOVA; $F$ (site) $=1,15$, $\mathrm{p}=\mathrm{ns} ; \quad F$ (season) $=0.48, \mathrm{p}=\mathrm{ns}$ ]. A similar pattern was observed for the bulk nitrogen content, with an annual average of $0.83 \%$ at the reference site and $0.87 \%$ at the mussel-line site. There was no significant difference due to site or season $[F($ site $)=1.614$, $\mathrm{p}=0.209_{i} F$ (season) $=1.08, \mathrm{p}=0.364 \mathrm{j}$. Using data from the period of April to August on sediment trap contents collected in the previous year, a comparison was made between the carbon concentration and the $\mathrm{C}: \mathrm{N}$ ratio of trap contents and the surface sediments at both sites. The carbon concentration of sediment trap contents at the reference site during that period in 1989 was $5.8 \%$ ( $\mathrm{SE}=1.6 \%, \mathrm{n}=14)$ and in the sediments from the 'skimmer cores' in 1990,6.8\% (SE = $0.23 \%, \mathrm{n}=11$ ). At the mussel-line site the carbon 
concentration of the sediment trap contents during the same period in 1989 was $7.4 \%(\mathrm{SE}=0.44 \%, \mathrm{n}=12)$ and in the sediments of the 'skimmer cores' in 1990, 8.3\% ( $\mathrm{SE}=1.60 \%, \mathrm{n}=11)$ Using $t$-tests, the differences in carbon concentration and $\mathrm{C}: \mathrm{N}$ ratios between the contents of the sediment traps sampled in 1989 and the sediments from the 'surface skimmer' cores sampled during the same period in 1990 were not significantly different $(p>0.05)$.

In 'profile' cores taken in mid November, porosities, and bulk carbon and nitrogen concentrations decreased with depth at both sites (Table 2). Carbon and nitrogen concentrations in the surface sediments $(0$ to $1.0 \mathrm{~cm}$ depth) of the mussel-line site were higher than at the reference site. Surface carbon concentrations in the deep cores (mean $=8.64 \%$ ) were the same as carbon concentrations of sediments sampled in the 'surface skim' cores in mid November at the mussel-line site $($ mean $=8.60 \%)$. There was more of a difference in the 2 sets of measurements at the reference site (deep core 0 to $1 \mathrm{~cm}$ depth $=8.6 \%$ and 'surface skim' core, mean $=7.60 \%$ ), but the difference was not significant ( $t$-test, $\mathrm{p}>0.05)$. The carbon concentration of the sediments at 9 to $10 \mathrm{~cm}$ depth were similar at the 2 sites, but the nitrogen concentrations remained elevated at the mussel-line site until 19 to $20 \mathrm{~cm}$ depth. Porosities remained higher in the core from the mussel-line site at all depths (Table 2).

\section{Benthic microalgal production}

Benthic gross production of the sediment surface samples (measured as oxygen production in light bottles) was negative in almost every case in light-dark bottle incubations from February to November, with irradiance at the bottom ranging from $<1 \%$ to $15 \%$ of surface values. These data indicate that photosynthetic oxygen production by epibenthic microalgae was less than that required for sediment respiration. Ice cover was present when measurements were made in Janu- ary to March, during which time irradiance profiles indicated that light did not reach the sediment surface. In only one case (June 28) was gross microalgal production positive, equivalent to an oxygen release of $4.6 \mathrm{mmol} \mathrm{O}_{2} \mathrm{~m}^{-2} \mathrm{~d}^{-1}$ Sediment oxygen consumption measured in cores on the same day was $28.8 \mathrm{mmol} \mathrm{O}_{2}$ $\mathrm{m}^{-2} \mathrm{~d}^{-1}$ (see below), an order of magnitude greater. We conclude that at these sites the calculation of sediment respiration based on dark core incubations is appropriate for both ice-free and ice-covered portions of the year.

\section{Sediment respiration and macrofauna}

The highest rates of oxygen consumption by the sediments were measured in the summer, during the period of highest chlorophyll concentration and water temperatures (Fig. 7). The largest site difference in oxygen demand was measured in May, on Days 123 and 124, approximately $33 \mathrm{~d}$ after the peak in chlorophyll concentration associated with the spring bloom (Fig. 2b).

The weights of macrofauna in the 'flux' cores ranged from 4 to $32 \mathrm{~g}$ dry $\mathrm{wt}^{-2}$, and were usually higher at the mussel-line site than at the reference site (Table 3). The between-site difference was largely due to abundant bivalves and gastropods in the sediments under the mussel-lines, particularly Nassarius spp. and Nuculana tenuisulcata (Grant et al. 1994).

When a stepwise regression model was applied to sediment respiration rate at the mussel-line site, the 3 significant predictors were water temperature, carbon content of surface sediments as measured in the 'surface skim' cores and dry wt of macrofauna in the 'flux' cores (Table 4). This regression model explains a significant $97 \%$ of the variance in sediment respiration at the mussel-line site. The same model explains $83 \%$ of the variability in sediment respiration rate at the reference site. In distinct contrast to the situation at the mussel-line site, the carbon content of surface sedi-

Table 2. Mean (SE) bulk carbon and nitrogen in sediments from 'profile' cores at 2 sites in Upper South Cove on November 15, 1990; carbon and nitrogen concentrations were measured on 3 replicate cores per site and porosities were calculated using data on water content of 1 core per site collected in August, 1991 (G. Winters \& R. Cranston unpubl. data)

\begin{tabular}{|c|c|c|c|c|c|c|}
\hline Variable & \multicolumn{3}{|c|}{ Reference site } & \multicolumn{3}{|c|}{ Mussel-line site } \\
\hline Sediment depth: & $\begin{array}{l}\text { Surface } \\
0-1.0 \mathrm{~cm}\end{array}$ & $9-10 \mathrm{~cm}$ & $19-20 \mathrm{~cm}$ & $\begin{array}{l}\text { Surface } \\
0-1.0 \mathrm{~cm}\end{array}$ & $9-10 \mathrm{~cm}$ & $19-20 \mathrm{~cm}$ \\
\hline Carbon (\% dry wt) & $\begin{array}{c}7.58 \\
(0.22)\end{array}$ & $\begin{array}{c}6.77 \\
(0.07)\end{array}$ & $\begin{array}{c}6.44 \\
\{0.05\}\end{array}$ & $\begin{array}{c}8.64 \\
(0.79)\end{array}$ & $\begin{array}{c}6.89 \\
(0.09)\end{array}$ & $\begin{array}{c}6.35 \\
(0.20)\end{array}$ \\
\hline Nitrogen (\% dry wt) & $\begin{array}{c}0.89 \\
(0.20)\end{array}$ & $\begin{array}{c}0.71 \\
(0.01)\end{array}$ & $\begin{array}{c}0.69 \\
(0.01)\end{array}$ & $\begin{array}{c}1.06 \\
(0.08)\end{array}$ & $\begin{array}{c}0.80 \\
(0.004)\end{array}$ & $\begin{array}{c}0.70 \\
(0.012)\end{array}$ \\
\hline Porosity $(\%)$ & 94.2 & 89.7 & 85.6 & 96.1 & 94.4 & 91.3 \\
\hline
\end{tabular}




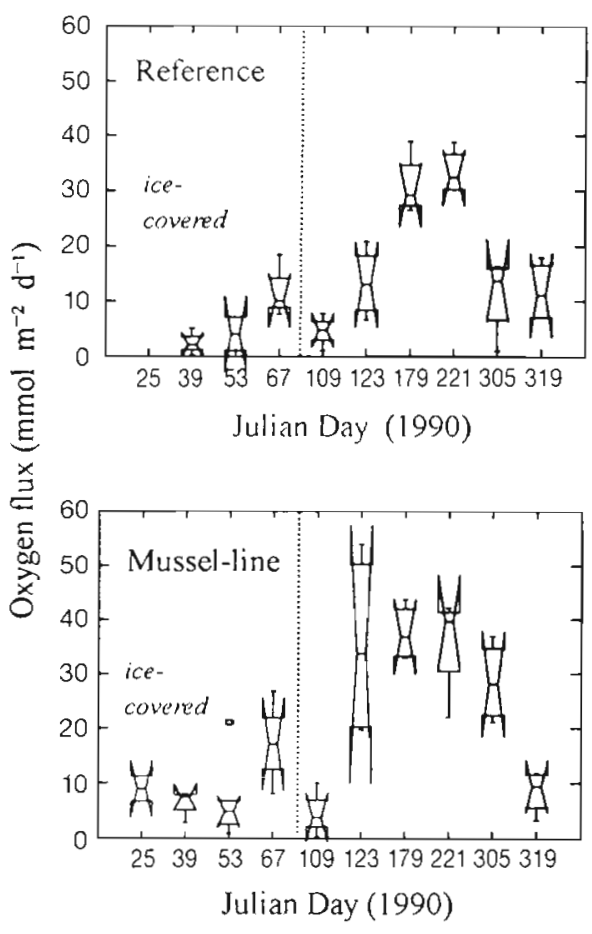

Fig. 7. Notched box and whiskers plots of sediment $\mathrm{O}_{2}$ consumption rate during 9 sampling trips to the reference site and 10 trips to the mussel-line site. In each box the median, which divides the data in half, is marked by a central line. The hinges split the remaining halves in half again. The notches show the $95 \%$ confidence interval (see Wilkinson et al. 1992). Julian days correspond to sampling trips listed in Table 1

Table 3. Weight of macrofauna [mean, g dry wt $\mathrm{m}^{-2}(\mathrm{SE})$ ] re tained on $500 \mu \mathrm{m}$ sieve in $25 \mathrm{~cm}$ sediment 'flux' cores

\begin{tabular}{|c|c|c|c|c|}
\hline \multirow{2}{*}{$\begin{array}{c}\text { Julian } \\
\text { day, } 1990\end{array}$} & \multicolumn{2}{|c|}{ Reference site } & \multicolumn{2}{|c|}{ Mussel-line site } \\
\hline & Weight & $n$ & Weight & n \\
\hline 25 & Missing & & 21.76 & 2 \\
\hline 39 & $\begin{array}{c}7.83 \\
(2.49)\end{array}$ & 3 & $\begin{array}{l}21.75 \\
(1.20)\end{array}$ & 3 \\
\hline 53 & 6.29 & 2 & $\begin{array}{r}15.39 \\
(9.58)\end{array}$ & 3 \\
\hline 67 & $\begin{array}{c}6.56 \\
(0.82)\end{array}$ & 3 & $\begin{array}{c}31.57 \\
(14.69)\end{array}$ & 3 \\
\hline 109 & $\begin{array}{c}14.6 \\
(5.68)\end{array}$ & 3 & $\begin{array}{c}9.19 \\
\{5.31\}\end{array}$ & 3 \\
\hline 123 & $\begin{array}{c}8.46 \\
(2.46)\end{array}$ & 4 & $\begin{array}{l}31.65 \\
(7.16)\end{array}$ & 4 \\
\hline 179 & Missing & & Missing & \\
\hline 221 & $\begin{array}{c}6.93 \\
(5.31)\end{array}$ & 4 & $\begin{array}{c}4.02 \\
(0.66)\end{array}$ & 4 \\
\hline 305 & $\begin{array}{c}3.78 \\
(0.66)\end{array}$ & 4 & $\begin{array}{l}29.69 \\
(0.66)\end{array}$ & 4 \\
\hline 319 & $\begin{array}{c}7.7 \\
(1.17)\end{array}$ & 4 & $\begin{array}{c}31.02 \\
(22.41)\end{array}$ & 4 \\
\hline
\end{tabular}

ment and weight of macrofauna are not significant predictors of sediment respiration rate at the reference site (Table 4 ), and water temperature alone explains $82 \%$ of the variance.

\section{Phosphorus fluxes}

Phosphate was predominantly taken up at both sites, with highest uptake occurring at the warmest time of year (Fig. 8). Temperature explained $50 \%$ of the variability in $\mathrm{PO}_{4}{ }^{3-}$ exchange rates at the reference site and $34 \%$ at the mussel-line site (Table 5). Inorganic phosphorus represented the bulk of the dissolved phosphorus flux. DOP was exchanged at low rates at both sites (Fig. 9), with the predominant flux being uptake.

\section{Nitrogen fluxes}

Ammonium was released from the sediments at both sites except in a few instances (Fig. 10). Rates increased on Day 109 (April 19) at the reference site, and remained elevated until Day 221 (August 10), after which the rates dropped to winter levels. A different pattern of much higher rates was observed at the mussel-line site, which more closely tracked the pattern of temperature change. Rates were higher during the period of May to November (Days 123 to 305) than in winter to early spring. At the mussel-line site,

Table 4. Sediment core respiration rate related to mean water temperature, carbon concentration of newly deposited sediment and weight of macrofauna at 2 sites ( $n=8$ at each site because the macrofauna samples for 2 sampling trips were lost). Multiple regression model derived using forward stepwise regression for the mussel-line site. The same model was then applied to the reference site (see text). Regression equation: $\mathrm{O}_{2}$ flux (mmol m$\left.{ }^{-2} \mathrm{~d}^{-1}\right)=C+\left[A \times\right.$ Temperature $\left.\left({ }^{\circ} \mathrm{C}\right)\right]+$ $[B \times$ Carbon $(\%)]+\left[D \times\right.$ Macrofauna (g dry wt $\left.\mathrm{m}^{-2}\right)$. ns: variable was not a significant predictor at that site

\begin{tabular}{|lcccccc|}
\hline Variable Coefficient & $t$ & $p$ & $F$ & $p$ & $r^{2}$ \\
\hline Reference site & & & & & \\
Constant & $C=-4.88$ & -0.22 & 0.838 & & & \\
Temp. & $A=1.45$ & 3.50 & 0.025 & & & 0.82 \\
Carbon & $B=1.62$ & 0.49 & 0.651 & & & ns \\
Macrof. & $D=-0.39$ & -0.54 & 0.616 & & & ns \\
& & Regression: & 6.68 & 0.049 & 0.83 \\
Mussel-line site & & & & & \\
Constant & $C=3.23$ & 6.16 & 0.004 & & & \\
Temp. & $A=1.48$ & 8.08 & 0.001 & & & 0.53 \\
Carbon & $B=-8.89$ & -6.41 & 0.003 & & & 0.93 \\
Macrof. & $D=0.11$ & 2.32 & 0.081 & & & 0.97 \\
& & Regression: & 41.99 & 0.002 & 0.97 \\
& & & & & \\
\end{tabular}




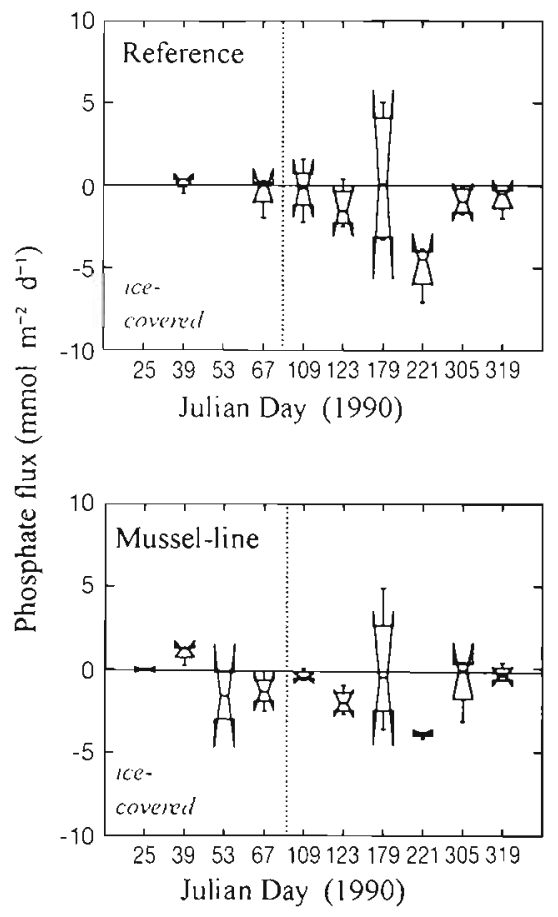

Fig. 8. Notched box and whiskers plots of sediment phosphate exchange during 9 sampling trips to the reference site and 10 trips to the mussel-line site, positive values indicate release from the sediment to the water column and negative values indicate uptake by the sediments from the water

temperature explained $63 \%$ of the variation in $\mathrm{NH}_{4}^{+}$ fluxes over the year whereas, at the reference site, the relationship between $\mathrm{NH}_{4}^{+}$flux and temperature was not significant (Table 5). When the data were grouped according to season, the highest mean fluxes were measured in the spring at the reference site and spring/summer at the mussel-line site. The site differences were significant but the season and site $\times$ season interaction factors were not (2-way ANOVA, $F$ (site) $=$ 11.5, $\mathrm{p}<0.001 ; F$ (season) $=2.29, \mathrm{p}=0.088 ; F($ site $x$ season $)=1.76, p=0.166)$.

Table 5. Sediment core phosphate and ammonium flux rates related to water temperature using linear regression at 2 sites in Upper South Cove. Regression equations are based on mean values at each sampling period ( $\mathrm{n}=9$ for the reference site and $\mathrm{n}=10$ for the mussel-line site). Regression equation: Flux $\left(\mathrm{mmol} \mathrm{m}{ }^{-2} \mathrm{~d}^{-1}\right)=C+\left[A \times\right.$ Temperature $\left.\left({ }^{\circ} \mathrm{C}\right)\right]$

\begin{tabular}{|lrcccc|}
\hline & $F$ & $\mathrm{p}$ & $\mathrm{r}^{2}$ & $\mathrm{C}$ & $\mathrm{A}$ \\
\hline $\begin{array}{l}\text { Phosphate flux } \\
\text { Reference site }\end{array}$ & 7.01 & 0.033 & 0.51 & 0.145 & -0.164 \\
Mussel-line site & 4.03 & 0.081 & 0.34 & - & - \\
Ammonium flux & & & & & \\
Reference site & 0.11 & 0.075 & 0.02 & - & - \\
Mussel-line site & 13.66 & 0.006 & 0.63 & 4.162 & 0.716 \\
\hline
\end{tabular}

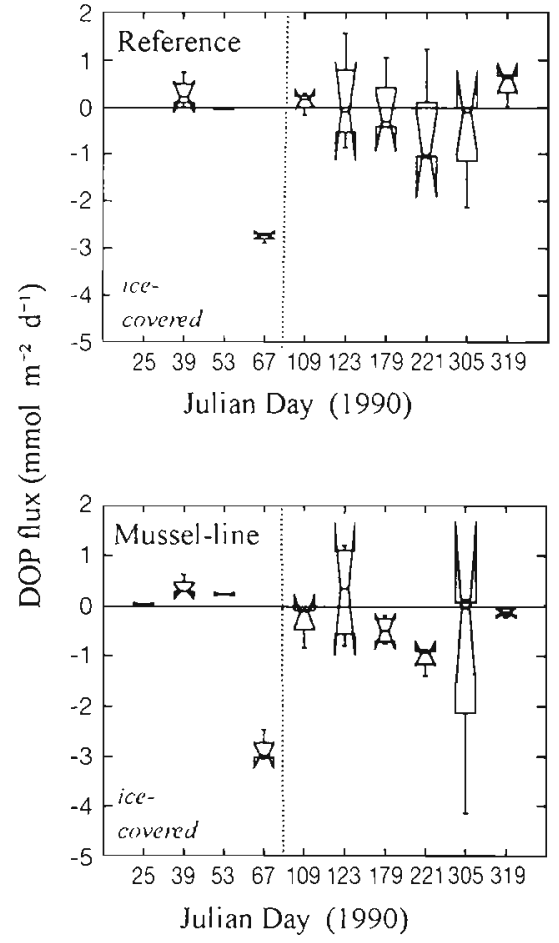

Fig. 9. Notched box and whiskers plots of sediment dissolved organic phosphorus (DOP) exchange during 9 sampling trips to the reference site and 10 trips to the mussel-line site. Sign convention as in Fig. 8

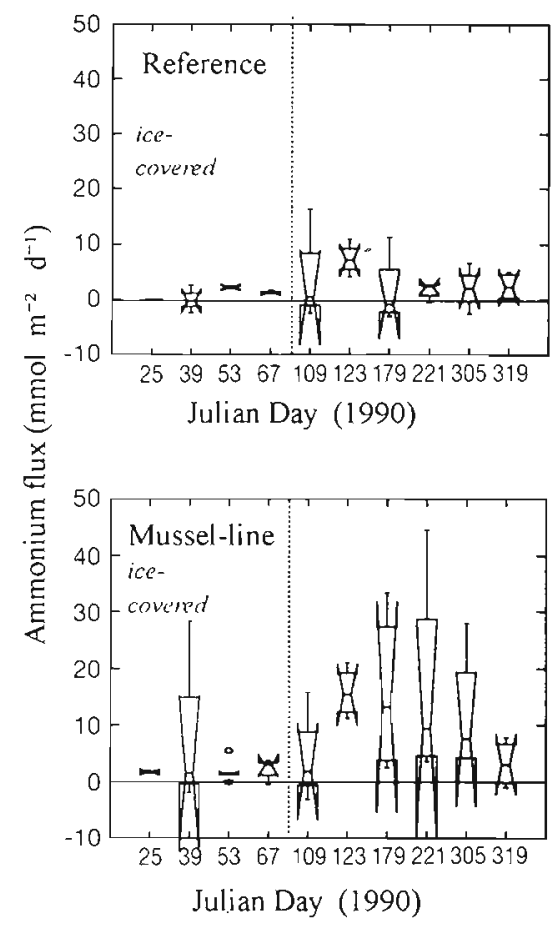

Fig. 10. Notched box and whiskers plots of sediment ammonium efflux during 9 sampling trips to the reference site and 10 trips to the mussel-line site. Sign convention as in Fig. 8 
The relationship between temperature and $\mathrm{NH}_{4}{ }^{+}$flux and respiration rates at the mussel-line site is probably due to increased microbial activity with an increase in temperature: a standard physiological response. Using a stepwise regression, a model was developed which explained $84 \%$ of the annual variation in $\mathrm{NH}_{4}{ }^{+}$flux using the 2 variables sediment respiration and ambient nearbottom $\mathrm{NO}_{3}{ }^{-}$concentrations (Table 6 ). The relationship between temperature and metabolic activity enhancing $\mathrm{NH}_{4}{ }^{+}$flux and sediment respiration is explainable on strictly physiological grounds at the mussel-line site, but it is not clear why the relationship was not significant at the reference site. There may be many different explanations for the relationship between $\mathrm{NH}_{4}{ }^{+}$flux and ambient near-bottom $\mathrm{NO}_{3}{ }^{-}$concentrations. Since sediment respiration and near-bottom $\mathrm{NO}_{3}{ }^{-}$concentrations are positively correlated with temperature over the year, temperature was left out of this model. In contrast, the same model was applied to the data from the reference site, and it explained only $39 \%$ of the variation in $\mathrm{NH}_{4}{ }^{+}$ flux over the same time period, and respiration was not a significant predictor (Table 6). Ambient near-bottom water $\mathrm{NO}_{3}{ }^{-}$concentrations were significant predictors of sediment $\mathrm{NH}_{4}{ }^{+}$flux at both sites (Table 6). Neither macrofaunal weight nor the $\mathrm{N}$ concentration of surface sediments were significant predictors of $\mathrm{NH}_{4}{ }^{+}$flux at either site.

Nitrate fluxes were usually $<10 \%$ of the $\mathrm{NH}_{4}{ }^{+}$fluxes, and a similar pattern was observed at both sites (Fig. 11) which was not statistically related to water temperature. A strong net uptake was measured on Day 25 at the mussel-line site and Days 39 (February 8 ) and 319 (November 15) at both sites, with low release rates measured during the rest of the year. Rates of $\mathrm{NO}_{2}{ }^{-}$

Table 6 . Sediment core ammonium flux rate related to sediment respiration rate and nitrate concentrations of overlying water at 2 sites. Multiple regression model derived using forward stepwise regression (see text) and eliminating variables with a minimum tolerance $>0.01$ Regression equation: $\mathrm{NH}_{4}^{+}$flux $\left(\mathrm{mmol} \mathrm{m}{ }^{-2} \mathrm{~d}^{-1}\right)=C+[A \times$ Sediment respiration rate (mmol O $\left.\left.\mathrm{O}_{2} \mathrm{~m}^{-2} \mathrm{~d}^{-1}\right)\right]+\left[\mathrm{B} \times \mathrm{NO}_{3}{ }^{-}\right.$concentration $\left.(\mu \mathrm{M})\right]$ $n$ s: variable was not a significant predictor at this site

\begin{tabular}{|c|c|c|c|c|c|c|}
\hline Variable & Coefficient & $t$ & $\mathrm{p}$ & $F$ & $p$ & $r^{2}$ \\
\hline \multicolumn{7}{|c|}{ Reference site } \\
\hline Constant & $C=4.39$ & 3.31 & 0.016 & & & \\
\hline $\mathrm{O}_{2}$ flux & $A=0.002$ & 0.04 & 0.971 & & & ns \\
\hline \multirow{2}{*}{$\mathrm{NO}_{3}^{-} \operatorname{conc}}$. & $B=-1.73$ & -1.93 & 0.101 & & & 0.39 \\
\hline & & \multicolumn{2}{|c|}{ Regression: } & 1.92 & 0.227 & 0.39 \\
\hline \multicolumn{7}{|c|}{ Mussel-line site } \\
\hline Constant & $C=3.23$ & 1.70 & 0.133 & & & \\
\hline $\mathrm{O}_{2}$ flux & $A=0.35$ & 5.08 & 0.001 & & & 0.76 \\
\hline \multirow{2}{*}{$\mathrm{NO}_{3}$ conc. } & $B=-0.91$ & -1.90 & 0.099 & & & 0.84 \\
\hline & & \multicolumn{2}{|c|}{ Regression: } & 18.68 & 0.002 & 0.84 \\
\hline
\end{tabular}

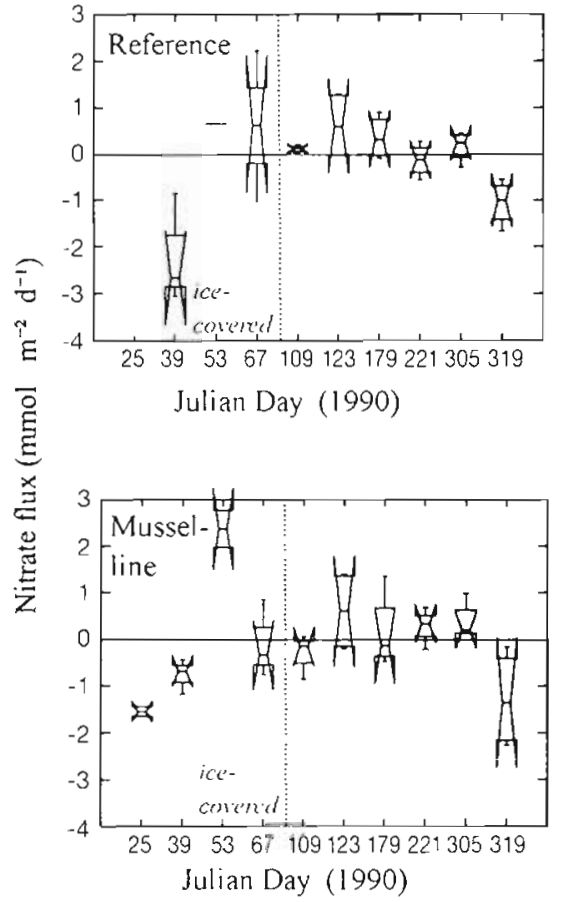

Fig. 11 Notched box and whiskers plots of sediment nitrate exchange during 9 sampling trips to the reference site and 10 trips to the mussel-line site. Sign convention as in Fig. 8

flux were about $20 \%$ of the $\mathrm{NO}_{3}{ }^{-}$flux rates (data not shown) and showed no significant pattern. When the data were grouped according to season, there were no significant differences due to site, season or the site $\times$ season interaction (2-way ANOVA).

DON was predominantiy taken up by the sediments at both sites (Fig. 12), at similar rates as $\mathrm{NH}_{4}{ }^{+}$efflux. $\mathrm{A}$ strong efflux was measured at the mussel-line site in January and February. The highest and most variable uptake rates were measured on May 3 (Day 123) at both sites, and the lowest and least variable on April 19 (Day 109). On Day 221 (August 10), a net efflux was measured at the reference site and a net uptake at the mussel-line site (Fig. 12). The rate of DON flux was positively correlated with oxygen consumption rate at the mussel-line site $(r=0.649, n=9, p<0.05)$, meaning that higher rates of DON influx were associated with higher respiration rates. These fluxes were not correlated at the reference site.

The net flux of total dissolved nitrogen was estimated by summing the fluxes within each core, and the results were examined on a seasonal basis (Table 7). The reference site showed a net uptake of total dissolved nitrogen, on average, in summer and autumn while a net efflux was calculated for the mussel-line site during all seasons, on average. The largest contributor to this between-site difference is $\mathrm{NH}_{4}{ }^{+}$efflux, and the significantly higher rates measured at the mussel-line site. 


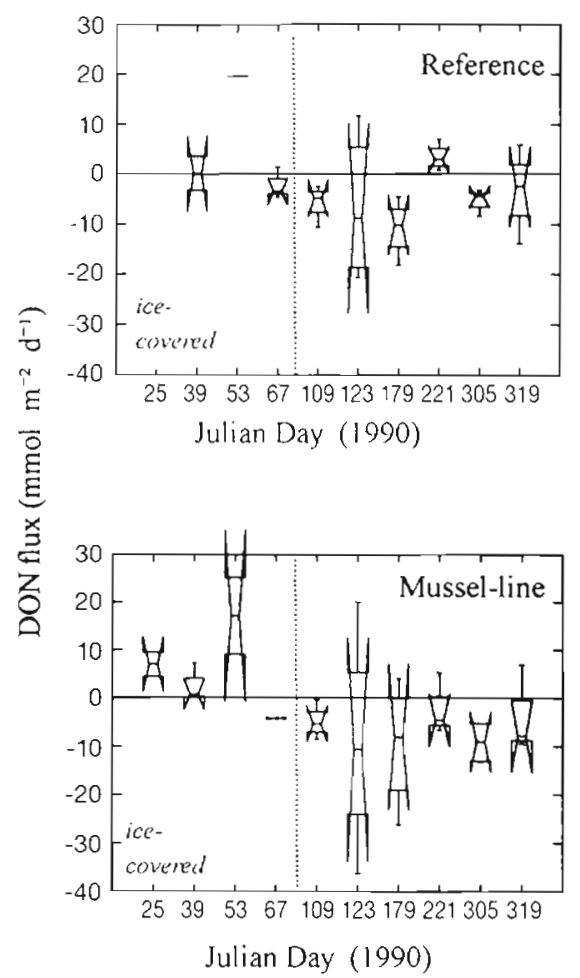

Fig. 12. Notched box and whiskers plots of sediment dissolved organic nitrogen (DON) exchange during 9 sampling trips to the reference site and 10 trips to the mussel-line site. Sign convention as in Fig. 8

\section{DISCUSSION}

\section{Sedimentation}

Most forms of aquaculture contribute to enhanced sedimentation of organic material proximal to the culture units (Hall et al. 1990, Jaramillo et al. 1992). The annual mean sedimentation rate at the reference site ( $36.4 \mathrm{~g}$ dry wt $\left.\mathrm{m}^{-2} \mathrm{~d}^{-1}\right)$ in Upper South Cove was in the range reported by Novitsky (1990) for nearby Halifax Harbour ( 26.2 to $55.2 \mathrm{~g}$ dry wt $\mathrm{m}^{-2} \mathrm{~d}^{-1}$ ), using sediment traps of the same design. The sedimentation rate for the mussel-line site $\left(88.7 \mathrm{~g}_{\text {dry }} \mathrm{wt} \mathrm{m}^{-2} \mathrm{~d}^{-1}\right)$,

Table 7. Seasonal mean uptake $(-)$ and release $(+)$ rates (standard errors) of total dissolved nitrogen ( $\mathrm{mmol} \mathrm{m} \mathrm{m}^{-2} \mathrm{~d}^{-1}$ ) from sediment cores taken in Upper South Cove

\begin{tabular}{|lcc|}
\hline Season & $\begin{array}{c}\text { Reference site } \\
\text { Mean flux (SE) }\end{array}$ & $\begin{array}{c}\text { Mussel-line site } \\
\text { Mean flux (SE) }\end{array}$ \\
\hline Winter $(n=8)$ & $3.41(4.27)$ & $9.72(3.82)$ \\
Spring $(n=13)$ & $0.29(4.08)$ & $3.96(5.93)$ \\
Summer $(n=8)$ & $-3.46(4.92)$ & $11.59(8.33)$ \\
Autumn $(n=8)$ & $-2.41(2.38)$ & $1.75(3.05)$ \\
\hline
\end{tabular}

although significantly higher than the reference site, is still low compared to rates measured under a fish farm [155.6 g dry wt $\mathrm{m}^{-2} \mathrm{~d}^{-1}$ estimated from data in Hall et al. (1990)] or a shallow-water mussel culture site in Spain (553 g dry wt $\mathrm{m}^{-2} \mathrm{~d}^{-1}$; Jaramillo et al. 1992). Using the annual mean sedimentation rates and the average carbon concentrations of sediment trap contents in the April to August 1989 period, the potential input of carbon through sedimentation at the musselline site can be estimated as approximately 3.5 times that at the reference site (Fig. 13). Both sites were within the range reported in Hargrave (1994) for Upper South Cove of 45 to $1875 \mathrm{mmol} \mathrm{C} \mathrm{m}^{-2} \mathrm{~d}^{-1}$.

\section{$\mathrm{Chl}$ a concentration and sedimentation}

Because only one logging fluorometer was available for this study, chl a concentrations were calculated only for the reference site. Any local changes in chl a concentrations due to the immediate presence of the mussel lines were not measured. The concentrations at the reference site were considered to be representative of temporal changes on a bay-wide average basis.

When the chl a concentrations at the reference site were compared to sedimentation rates at both sites, a positive linear relationship emerged at concentrations less than $4.0 \mathrm{\mu g} \mathrm{l}^{-1}$. The relationship may change above this 'threshold' concentration for many reasons. The species of phytoplankton which are present at

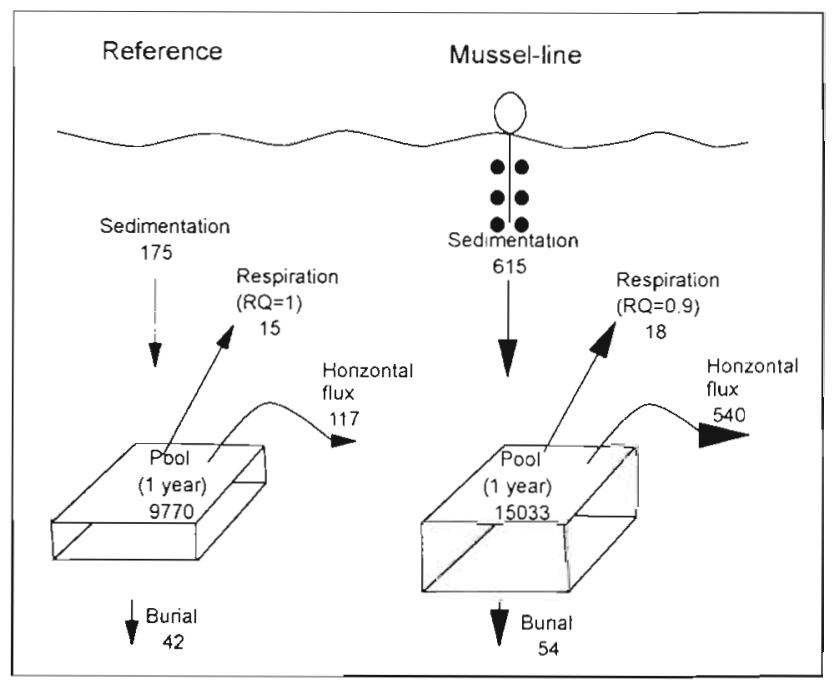

Fig. 13. Summary of annual mean carbon fluxes at 2 sites. Straight lines represent measured and calculated fluxes. The horizontal flux is calculated by difference, and could include resuspended or remobilized vertical flux, DOC efflux and loss in itinerant macrofaunal biomass. All units are mmol m-2 $\mathrm{d}^{-1}$ except sediment pool $\left(\mathrm{mmol} \mathrm{m} \mathrm{m}^{-2} \mathrm{yr}^{-1}\right)$ and are rounded to the nearest whole number 
higher concentrations may be bloom species which are more buoyant. Alternatively, higher chl a concentrations may occur during stratified conditions, when sedimentation rates may be lower We do not have the data on phytoplankton species composition which is required to resolve these explanations.

\section{Sediment respiration}

In Upper South Cove, the highest rates of sediment respiration were measured in summer at the musselline site. The mean summer rate of $36 \mathrm{mmol} \mathrm{O}_{2} \mathrm{~m}^{-2}$ $\mathrm{d}^{-1}$ is close to rates measured under a mussel culture site in France ( $48 \mathrm{mmol} \mathrm{O}_{2} \mathrm{~m}^{-2} \mathrm{~d}^{-1}$ ) (Baudinet et al. 1990). As pointed out by Hargrave et al. (1993), the sediment respiration rates observed in the Bay of Fundy (including sediments directly under salmon pens), do not fall significantly outside the normal range for similar, unimpacted bays. The same is true for the sediment respiration rates measured in Upper South Cove. Benthic oxygen consumption may not be a sensitive indicator of higher organic input from mussel culture because of increased activity of the sulphur cycle, and storage of end products such as pyrite (Holmer \& Kristensen 1992).

Unlike the results of Hargrave et al. (1993), there is a strong coupling between water temperature and sediment respiration rate at the 2 sites in Upper South Cove. The lack of a significant correlation between temperature and respiration rate in the study of Hargrave et al. (1993) was attributed to the accumulation of sulphides which lagged seasonal temperature increases and caused high rates of chemical oxygen demand under salmon pens. If this explanation applies to Upper South Cove, we may conclude that oxidation of accumulated sulphides is not a significant component of sediment oxygen demand because there was a strong relationship between temperature and sediment respiration at the 2 sites. Further support for this conclusion comes from a comparison between the 2 sites in Upper South Cove. The relationship between temperature and sediment respiration was weaker at the mussel-line site than at the reference site, and there was a much stronger gradient of hydrogen sulphide in deep sediment cores. At the mussel-line site, concentrations of $10 \mathrm{ppm}$ of hydrogen sulphide were measureable at $6 \mathrm{~cm}$ below the sediment surface, and a consistent gradient was measured which rose to 196 ppm at $44 \mathrm{~cm}$ depth (Grant et al. 1994). In contrast, concentrations of hydrogen sulphide at the reference site were not measureable until a depth of $30 \mathrm{~cm}$ (2 ppm), which rose to 41 ppm at $40 \mathrm{~cm}$ depth.

Along with the proposed involvement of sulphide accumulation in the relationship between temperature and sediment respiration, there are indications that macrofauna may influence the rates of sediment respiration at the mussel-line site more than the reference site. The role of the macrofauna in turning over the sediments is not known. The present study concentrated on differences in macrofaunal biomass. The regression model chosen after stepwise iterations incorporated 3 significant predictors of respiration of mussel-line sediments (water temperature, carbon concentration of surface sediments and the biomass of macrofauna), whereas, at the reference site, only water temperature was a significant predictor.

The biomass of macrofauna under the mussel lines was higher than the reference site at all sampling times, and in combination with the availability of respiratory substrate (carbon in surface sediments) had a significant influence on sediment respiration. This influence could be due to higher biomasses, higher abundances of various taxa or larger individuals at the mussel-line site. The most significant differences observed were higher abundances of gastropods at the mussel-line site, particularly in the fall and higher abundances of polychaetes at the reference site, particularly in the summer (Grant et al. 1994). The most striking between-site difference in respiration occurred in the spring. At that time, the species composition of macrofauna was similar at the 2 sites with the exception of a much higher abundance of amphipods at the mussel-line site, which may have contributed to the higher sediment respiration. Another factor which may play a role in the between-site differences concerning the influence of macrofauna on sediment respiration is the average weight per individual. The average individual's weight was always higher at the mussel-line site. The most significant differences occurred in the spring (a 3-fold difference of $1 \mathrm{mg}$ dry $w \mathrm{t}$ ind.- ${ }^{-1}$ at the reference site and 4.3 at the mussel-line site) and in the fall (a 4.6 times difference of $0.4 \mathrm{mg}$ dry wt ind ${ }^{-1}$ at the reference site and $5.0 \mathrm{at}$ the mussel-line site). These are the times of the year when the between-site differences in sediment respiration were highest.

To compare various fluxes and pools associated with carbon cycling at the 2 sites in Upper South Cove, we needed to estimate an $\mathrm{RQ}$ (respiratory quotient; $\mathrm{CO}_{2}$ production rate $/ \mathrm{O}_{2}$ consumption rate) to convert sediment respiration from measured oxygen uptake to calculated carbon dioxide release. The RQ was estimated at both sites by a consideration of the relative magnitude of some chemical oxidative processes. The contribution of these processes to sediment oxygen demand was assessed by an examination of the porewater profiles of hydrogen sulphide and solid-phase iron measured on cores collected at both sites in August, as described in Grant et al. (1994). This is the time of year 
when the water temperature is near maximum, so measured profiles are probably at the higher end of the annual cycle. However, we do not have seasonal data. Using a calculated diffusion coefficient (Berner 1980) and these measured gradients, diffusion of hydrogen sulphide at the reference site was calculated to be approximately $0.3 \mathrm{mmol} \mathrm{m}^{-2} \mathrm{~d}^{-1}$ and 1.49 at the mussel-line site. With an approximate stoichiometry of $1: 2.5$ (Stumm \& Morgan 1981), this diffusion rate could account for $10 \%$ of the calculated oxygen consumption rate of the mussel-line sediments (for sulphide oxidation) whereas sulphide oxidation fueled by sediment diffusion could only account for $1 \%$ of the oxygen consumption rate of sediments at the reference site (Fig. 13). A consideration of the solid-phase iron profiles at the 2 sites (G. Winters and R. Cranston unpubl. data) suggests that approximately $0.03 \mathrm{mmol} \mathrm{m}^{-2} \mathrm{~d}^{-1}$ (total iron) could be remobilized and oxidized at the mussel-line site. With a 1:4 stoichiometry (Stumm \& Morgan 1981), this could account for $0.12 \mathrm{mmol} \mathrm{m}^{-2}$ $\mathrm{d}^{-1}$ oxygen demand, a fraction of the calculated oxygen demand for sulphide oxidation, and a flux that would not appreciably alter the $R Q$ ratio at either site. There was no evidence of iron remobilization in the core profile taken at the reference site. Taking the oxygen demand for sulphide oxidation into account, an $\mathrm{RQ}$ of around 0.9 is calculated for the sediments at the mussel-line site and 1.0 at the reference site. These are considered minimum estimates, because the only delivery to the sediment surface considered was through diffusion and not nitrate reduction. If irrigation and bioturbation are significant processes in these sediments, the estimates of oxygen demand for oxidation of sulphides could be much higher, particularly at the mussel-line site. Chemical oxygen demand of sediment communities under fish pens can account for up to $100 \%$ of sediment respiration rate (Holmer \& Kristenson 1982, Hargrave et al. 1993). Using the calculated $\mathrm{RQ}$ ratios, $\mathrm{CO}_{2}$ flux was estimated using the annual mean oxygen demand at the 2 sites, which was $15 \mathrm{mmol} \mathrm{m} \mathrm{m}^{-2} \mathrm{~d}^{-1}$ at the reference site and 18 at the mussel-line site (Fig. 13).

\section{Impacts of suspended mussel culture on the sedimentary carbon cycle}

We have data on many of the fluxes associated with carbon deposition and remineralization at 2 sites in Upper South Cove. To compare these fluxes, we calculated averages over the year of measurement (Fig. 13). Using the net sedimentation rates of $1.0 \mathrm{~cm} \mathrm{yr}^{-1}$ for the reference site and $2.3 \mathrm{~cm} \mathrm{yr}^{-1}$ at the mussel-line site (Grant et al. 1994), carbon concentration and porosity of sediments in cores, an annual carbon burial rate was calculated at the 2 sites. This rate and the average respiration and sedimentation rates were compared to the pool of carbon in the surface sediments (a 1 yr pool = $1.0 \mathrm{~cm}$ depth at the reference site and 2.3 at the mussel-line site) (Fig. 13). As is apparent in Fig. 13, the sedimentation flux as measured in traps is disproportionately larger than the other fluxes. This flux was about 5 to 10 times the net annual sedimentation rate as measured in sediment cores. This discrepancy may arise because the sediment traps oversample sedimentation, accumulating material entrained in the horizontal flux as well as the vertical. Alternatively or additionally, most of the particulate material caught in the traps either does not make it to the benthos or is quickly remobilized. This loss through remobilization may be as DOC, macrofaunal biomass or export. The calculated horizontal tidal flux of 613 to $2374 \mathrm{~g}$ dry wt $\mathrm{m}^{-2} \mathrm{~h}^{-1}$ could represent 36 to $138 \mathrm{~mol} \mathrm{C} \mathrm{m} \mathrm{m}^{-2} \mathrm{~d}^{-2}$ (assuming that $\mathrm{C}=5.8 \%$ dry $w t$, which is the average for the sediment trap contents) at the reference site. This flux is much larger than the proposed horizontal fluxes calculated by difference and presented in Fig. 13. Because we have not formulated a bay-wide budget, we do not know the ultimate fate of the material transported from the sites. These calculations indicate that the sedimentation rate as measured by traps is an overestimate, and that most of the trapped material could be exported from the site rather than being incorporated in the sediments. In shallow marine systems, sediment traps can sample horizontal as well as vertical fluxes of particulate material, leading to overestimates of sedimentation rate (Hargrave 1994). The average sediment respiration rate is $20 \%$ higher at the mussel-line site, but this carbon loss is equivalent to only $36 \%$ of the calculated long-term burial rate at the reference site and $33 \%$ at the mussel-line site. However, the sediment respiration rates used are underestimates because of the limited data used to estimate chemical oxygen demand to derive $\mathrm{CO}_{2}$ efflux from $\mathrm{O}_{2}$ influx measurements. Long-term burial is estimated to be approximately $29 \%$ higher at the musselline site than the reference site.

\section{Phosphorus flux}

In a recent review, Sundby et al. (1992) identified the oxidized surface layer of marine sediments as a trap for $\mathrm{PO}_{4}{ }^{3-}$, largely due to the presence of iron oxides. Winters \& Cranston (unpubl. data) have found high total iron concentrations in the sediments of Upper South Cove ( $4 \%$ by weight), with a large percentage of labile components ( $1 \%$ by weight in surface sediments). The labile fraction was calculated as the sum of the sequential leach analysis components (weak acid 
leach + hydroxyalmine leach + heated hydroxylamine leach; Chester \& Hughes 1967, Tessier et al. 1979). Because of the oxygenated state of the surface sediments and the high labile iron concentration, the sediments of Upper South Cove form an efficient sink for $\mathrm{PO}_{4}{ }^{3-}$.

We suggest that phosphate uptake by the sediments of Upper South Cove is largely due to the high concentrations of iron in these sediments. However, we do not know why there is such a strong relationship between phosphate uptake rate and water temperature. The effect of temperature on the many chemical adsorption/desorption reactions involving $\mathrm{PO}_{4}{ }^{3-}$ has not been investigated thoroughly. A strong coupling between temperature and sediment-water phosphorus flux has been noted in several papers, but uptake has not been partitioned between biologically mediated and chemically mediated processes in these studies. Rizzo (1990), Dollar et al. (1991) and Falcao \& Vale (1990) measured effluxes which were positively related to temperature in Chesapeake Bay, Tomales Bay (California, USA) and Ria Formosa (Portugal) respectively. However, Propp et al. (1980) found that $\mathrm{PO}_{4}{ }^{3-}$ efflux from sediments in Vostok Bay (Russia) was negatively correlated with temperature, as was the case in Upper South Cove.

The average influx of phosphate at the 2 Upper South Cove sites was approximately $1 \mathrm{mmol} \mathrm{m}^{-2} \mathrm{~d}^{-1}$. If particulate phosphorus is buried in approximately 'Redfield' stoichiometry with carbon, this influx of $\mathrm{PO}_{4}{ }^{3-}$ would result in a $\mathrm{C}: \mathrm{P}$ ratio at depth in the sediments of approximately $30: 1$ at the reference site and $36: 1$ at the mussel-line site.

\section{Ammonium flux}

Benthic $\mathrm{NH}_{4}{ }^{+}$fluxes at Upper South Cove reached a

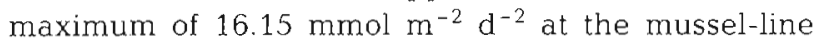
site during the summer. $\mathrm{NH}_{4}{ }^{+}$fluxes measured in Upper South Cove were within the range for various undisturbed coastal sediments $(0.30$ to $17.04 \mathrm{mmol}$ $\mathrm{m}^{-2} \mathrm{~d}^{-1}$; Nixon 1981), and higher than reported fluxes associated with some other shellfish culture sites (1.2 to $8.9 \mathrm{mmol} \mathrm{m} \mathrm{m}^{-2} \mathrm{~d}^{-1}$; Boucher \& BoucherRodoni 1988, Baudinet et al. 1990). Although the rates of $\mathrm{NH}_{4}{ }^{+}$efflux from mussel-line sediments in Upper South Cove fall at the high end of 'normal', and are higher than some other reported shellfish farm sediments, they fall well below the rates measured by Hargrave et al. (1993) under salmon pens (maximum $62 \mathrm{mmol} \mathrm{m}^{-2} \mathrm{~d}^{-1}$ ).

$\mathrm{NH}_{4}{ }^{+}$efflux from the sediments at the 2 sites in Upper South Cove is probably a result of many processes in addition to the delivery and reduction of particulate nitrogen from the overlying water. The evidence for this statement is based on a prediction of $\mathrm{NH}_{4}{ }^{+}$flux which is based on sediment respiration and on a comparison of the relative magnitude of $\mathrm{NH}_{4}^{+}$ fluxes at the 2 sites over the year. Measured $\mathrm{NH}_{4}{ }^{+}$ efflux is higher than the calculated flux based on sediment oxygen demand, the $R Q$ and the $C: N$ ratio of the particulate substrate by 1.7 times at the reference site and 2.5 times at the mussel-line site (using averages in Figs. 13 \& 14). Comparing seasonally averaged fluxes, $\mathrm{NH}_{4}{ }^{+}$efflux at the mussel-line site is 10 times higher than at the reference site during the summer period. This difference is much higher than would be predicted simply from the difference in sedimentation (mussel-line site sedimentation is approximately 3 times higher than sedimentation at the reference site calculated from sediment trap data and 2.3 times higher net annual sedimentation).

There are many different processes that could contribute to $\mathrm{NH}_{4}{ }^{+}$flux in sediments which are independent of the delivery and reduction of particulate organic nitrogen. Two processes that we suggest may contribute to $\mathrm{NH}_{4}{ }^{+}$flux in Upper South Cove sediments are $\mathrm{NO}_{3}{ }^{-}$ammonification (Koike \& Sørensen 1988) and DON uptake and reduction. The proposed contribution of $\mathrm{NO}_{3}{ }^{-}$ammonification to $\mathrm{NH}_{4}{ }^{+}$flux stems from the negative relationship between bottom-water $\mathrm{NO}_{3}{ }^{-}$concentrations and $\mathrm{NH}_{4}{ }^{+}$flux at both sites. This pathway or the denitrification pathway may be responsible for some of the measured net $\mathrm{NO}_{3}{ }^{-}$uptake, particularly during the winter. Measured net $\mathrm{NO}_{3}{ }^{-}$uptake during the winter period is probably not due to autotrophs because there is no light penetration to the sediment surface. The resolution of these pathways awaits further examination of the processes involved.

\section{DON flux}

Dissolved organic nitrogen is potentially another substrate which could contribute to $\mathrm{NH}_{4}{ }^{+}$efflux after microbial degradation. DON influx is of similar magnitude to $\mathrm{NH}_{4}{ }^{+}$efflux at most times of the year, particularly at the mussel-line site. Also observed at the mussel-line site was a significant correlation between DON influx and oxygen consumption by the sediments. It can be suggested that DON pools in the overlying water are of greater importance to the bacterial populations in the mussel-line sediments, indicated by uptake in direct proportion to metabolic activity, as measured by sediment respiration. Because of the large pool of DON in the overlying water and the low water residence time, this uptake would not necessarily change measured concentrations in the overlying water. Although there are many studies examining fluxes of nutrients between sediments and water, very 
few of these include fluxes of DON. Those studies that have included DON have found low and variable fluxes (Propp et al. 1980) which usually are from the water column to the sediment (Van Kessel 1977. Hopkinson \& Wetzel 1982). The inverse relationship between $\mathrm{NH}_{4}{ }^{+}$and DON fluxes associated with Upper South Cove sediments suggests that there could be an uptake and breakdown of DON mediated by the microbial community of the sediments

\section{Impacts of suspended mussel culture on the sedimentary nitrogen cycle}

Annual average nitrogen fluxes and pools were calculated in the same way as were the carbon fluxes, and summarized in Fig. 14. As is apparent in Fig. 14, the sedimentation flux as measured in traps is disproportionately larger than the other fluxes, as was the case with carbon. The mean influx rate of $\mathrm{DON}$, and $\mathrm{NO}_{3}{ }^{-}+$ $\mathrm{NO}_{2}{ }^{-}$was the same at the 2 sites. Long-term nitrogen burial is estimated to be approximately $25 \%$ higher at the mussel-line site than the reference site. The nitrogen budget for the 2 sites is not complete, because nitrogen fixation and denitrification were not measured. The most notable impact of suspended mussel culture was the high rate of $\mathrm{NH}_{4}{ }^{+}$efflux, at 3 times the rate measured at the reference site. Because of this high efflux, the sediment community under suspended

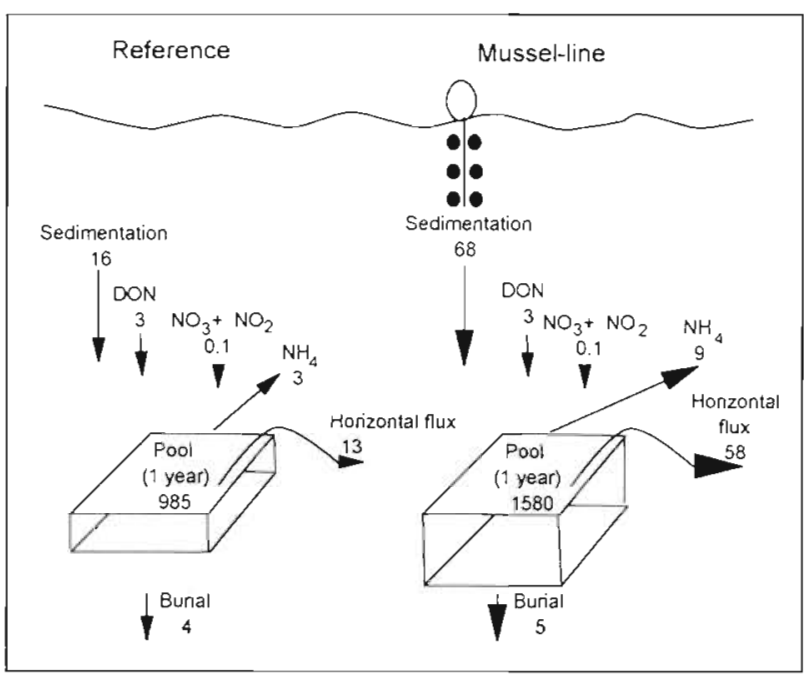

Fig. 14. Summary of annual mean nitrogen fluxes (arrangement and units as in Fig. 13). The horizontal flux is calculated by difference, and could include resuspended or remobilized vertical flux, gaseous nitrogen lost through denitrification pathways and nitrogen incorporated into itinerant macrofaunal biomass. An input which was not measured during this study was nitrogen fixation and an unmeasured loss was denitrification mussel culture is a net source of dissolved nitrogen; whereas, at the reference site, a net uptake was measured during the summer and autumn. The loss of nitrogen as $\mathrm{NH}_{4}^{+}$is $75 \%$ of the calculated long-term burial rate at the reference site, and $180 \%$ at the mussel-line site.

\section{SUMMARY AND CONCLUSIONS}

The ice-covered winter period in Upper South Cove was a period of low sedimentation. The spring phytoplankton bloom started in March 1990 while the Cove was still ice-covered, probably being advected in from Lunenburg Bay. Sediment respiration was low, but increased during the winter, as the spring bloom began. This period was characterized by low bottomwater concentrations of $\mathrm{NH}_{4}{ }^{+}$and high $\mathrm{NO}_{3}{ }^{-} . \mathrm{NH}_{4}{ }^{+}$flux was generally low, with the exception of the musselline site in early February. DON efflux was high at the mussel-line site, and this was the only time of year that a net efflux was measured. $\mathrm{NO}_{3}{ }^{-}$influx to the sediments was high in the early part of the season, when no light penetrated through the snow-covered ice to the sediment surface. Because of the unlikelihood of this uptake being driven by autotrophic processes, we suggest that the $\mathrm{NO}_{3}{ }^{-}$influx was driven by $\mathrm{NO}_{3}{ }^{-}$ reduction either through the denitrification or the $\mathrm{NO}_{3}{ }^{-}$ammonification microbial pathways.

In Upper South Cove, sedimentation rate, as measured by sediment traps, was a linear function of the chl a concentration in the water column up to $4.0 \mu \mathrm{g} \mathrm{I}^{-1}$ This relationship implies that phytoplankton settled out of the euphotic zone in Upper South Cove in proportion to its biomass. Feeding and biodeposition of mussels in suspended culture significantly enhanced sedimentation. This enhanced sedimentation was still linearly related to phytoplankton biomass, but at a higher rate. Suspended mussels doubled the amount of material settling into sediment traps per unit of phytoplankton biomass (measured as chl a), indicating that the suspended mussels enhanced pelagic to benthic coupling.

Most of the particulate organic matter which was trapped in sediment traps at the reference site and the mussel-line site did not contribute significantly to carbon or nitrogen flux or long-term burial in the underlying sediments. The bulk of this particulate organic matter was probably transported from both of the sites as tidally driven horizontal flux.

Respiration averaged $15 \mathrm{mmol} \mathrm{m} \mathrm{m}^{-2} \mathrm{~d}^{-1}$ at the reference site which was $36 \%$ of the long-term carbon burial. At the mussel-line site, respiration averaged $18 \mathrm{mmol} \mathrm{m}^{-2} \mathrm{~d}^{-1}$, about $33 \%$ of the long-term carbon burial. Long-term burial of carbon and nitrogen was 
higher at the mussel-line site than at the reference site by an average of $12 \mathrm{mmol} \mathrm{m} \mathrm{m}^{-2} \mathrm{~d}^{-1}$ (C) and $1 \mathrm{mmol}$ $m^{-2} d^{-1}(N)$.

The rate of $\mathrm{NH}_{4}^{+}$flux from the sediments was 6 mmol $\mathrm{m}^{-2} \mathrm{~d}^{-1}$ higher under suspended mussel culture than at the reference site, on average, and $10 \mathrm{mmol} \mathrm{m} \mathrm{m}^{-2} \mathrm{~d}^{-1}$ higher during the summer period. $\mathrm{NH}_{4}{ }^{+}$flux is much higher than would be predicted based on mineralization of particulate organic material, particularly at the mussel-line site. Thus, we suggest that $\mathrm{NH}_{4}^{+}$flux is influenced by other processes in addition to the delivery and reduction of particulate organic material. Two processes which may play a role in $\mathrm{NH}_{4}{ }^{+}$flux are $\mathrm{NO}_{3}{ }^{-}$ammonification and DON influx and decomposition. These suggestions are made based on the observed relationships between $\mathrm{NH}_{4}{ }^{+}$efflux rate and bottom-water $\mathrm{NO}_{3}{ }^{-}$concentrations at both sites, and on the positive relationship between DON influx and $\mathrm{NH}_{4}{ }^{+}$efflux at the mussel-line site.

The sediments of Upper South Cove form an efficient sink for phosphate, independent of the presence of suspended mussel culture. In contrast, the most striking effect of suspended mussel culture, as indicated by our data, was the enhancement of $\mathrm{NH}_{4}{ }^{+}$efflux. Thus, sediments under the mussel lines are a source for dissolved nitrogen, unlike the reference site sediments. The ratio of nitrogen to phosphorus in Upper South Cove waters will be altered by the presence of mussel lines, with concomitant changes in algal (epibenthic as well as planktonic) production and/or species composition. Whether the impact of the changing N:P ratio is a significant factor in influencing primary producers will depend on the areal extent of the culture lines and the biomass of mussels, but may be an impact of potentially greater magnitude that the rather small measured shifts in some of the fluxes associated with the sedimentary nutrient cycles.

Acknowledgements. This study was conducted at the Corkum Island Mussel Farm, Lunenburg Co., N.S. We thank the owner of the farm, D. Cook, for his assistance in many aspects of the work. Much of the diving involved was conducted by A. Mallet, and field logistics by C. Carver. C. Emerson assisted with the vast amounts of chlorophyll and temperature data. D. Scott, C. Younger and P. MacPherson collected the sediment cores in August 1991 for geochemical profiles, and G. Gouthro did the laboratory analyses. A. Mucci, B. Boudreau, P. Eldridge and J. Cornwell assisted with interpretation of data on sediment core geochenistry. P. Pocklington counted and identified the macrofauna and A. Griswold weighed and sorted them. J. Novitsky provided the data on sedimentation and $\mathrm{G}$. Winters provided data on sediment iron and hydrogen sulphide concentrations in sediment profiles. S. V. Smith provided helpful advice, and B. Hargrave reviewed the manuscript. The work was funded by an NSERC postdoctoral fellowship to A.H and NSERC Strategic Grants to J.G., K. Thompson and D. Scott

\section{LITERATURE CITED}

Baudinet, D., Alliot, E., Berland, B., Grenz, C., Plante-Cuny, M. Plante, R., Salen-Picard, C. (1990). Incidence of mussel culture on biogeochemical fluxes at the sediment-water interface. Hydrobiologia 207: 187-196

Berner, R. A. (1980). Early diagenesis: a theoretical approach. Princeton University Press, Princeton

Boucher, G., Boucher-Rodoni, R. (1988). In situ measurement of respiratory metabolism and nitrogen fluxes at the interface of oyster beds. Mar. Ecol. Prog. Ser. 44: 229-238

Chester, R., Hughes, M. J. (1967). A chemical technique for the separation of ferro-manganese minerals, carbonate minerals and adsorbed trace elements from pelagic sediment. Chem. Geol. 2: 249-262

Dollar, S. J., Smith, S. V., Vink, S. M., Obrebski, S., Hollibaugh, J. T. (1991). Annual cycle of benthic nutrient fluxes in Tomales Bay, California, and contribution of the benthos to total ecosystem metabolism. Mar. Ecol. Prog. Ser. 79: 115-125

Emerson, C., Grant, J., Mallet, A., Carver, C. (1994). Growth and survival of sea scallops, Placopecten magellanicus: effects of culture depth. Mar. Ecol. Prog. Ser. 108: $119-132$

Falcao, M., Vale, C. (1990). Study of the Ria Formosa ecosystem: benthic nutrient remineralization and tidal variability of nutrients in the water. Hydrobiologia 207: $137-146$

Grant, J., Hatcher, A., Scott, D. B., Pocklington, P., Schafer, C. T., Winter, G. (1994). A multidisciplinary approach to evaluating benthic impacts of shellfish aquaculture. Estuaries (in press)

Hall, P. O. J., Anderson, L. G., Holby, O., Kollberg, S., Samuelsson, M.-O. (1990). Chemical fluxes and mass balances in a marine fish cage farm. I. Carbon. Mar. Ecol. Prog. Ser. 61: 61-73

Hall, P. O. J., Holby, O., Kollberg, S., Samuelsson, M.-O. (1992). Chemical fluxes and mass balances in a marine fish cage farm. IV Nitrogen. Mar. Ecol. Prog. Ser. 89: $81-91$

Hargrave, B. T., Duplisea, D. E, Pfeiffer, E., Wildish, D. (1993). Seasonal changes in benthic fluxes of dissolved oxygen and ammonium associated with marine cultured Atlantic salmon. Mar. Ecol. Prog. Ser. 96: 249-257

Hargrave, B. (1994). Past and future studies with sediment traps in Canadian east coast waters. In: Wassmann, P. (ed.) Sediment trap studies in the Nordic countries 3. Symp. Proc. Tvärminne Zoological Station, Hanko, p. 1-15

Holme, N. A., McIntyre, A. D. (1984). Methods for the study of marine benthos. Blackwell Scientific Publications, Oxford

Holmer, M., Kristensen, E. (1992). Impact of marine fish cage farming on metabolism and sulfate reduction of underlying sediments. Mar. Ecol. Prog. Ser. 80: 191-201

Hopkinson, C. S., Wetzel, R. L. (1982). In situ measurements of nutrient and oxygen fluxes in a coastal marine benthic community. Mar. Ecol. Prog. Ser. 10: 29-35

Jaramillo, E., Bertran, C., Bravo, A. (1992). Mussel biodeposition in an estuary in southern Chile. Mar. Ecol. Prog. Ser. 82: $85-94$

Kaspar, H. F., Gillespie, P. A., Boyer, I. C., Mackenzie, A. L. (1985). Effects of mussel aquaculture on the nitrogen cycle and benthic communities in Kenepuru Sound. Marlborough Sound, New Zealand. Mar. Biol. 85: 127-136

Klump, J. V., Martens, C. S. (1981). Biogeochemical cycling in an organic rich coastal marine basin. II. Nutrient sediment-water exchange processes. Geochim. Cosmochim. Acta 45: 101-121 
Koike, I., Sørensen, J. (1988). Nitrate reduction and denitrification in marine sediments. In: Blackburn, T. H., Sorensen, J. (eds.) Nitrogen cycling in coastal marine environments. John Wiley \& Sons, London, p. 251-273

Koop, K., Boynton, W. R., Wulff, F., Carman, R. (1990). Sediment-water oxygen and nutrient exchanges along a depth gradient in the Baltic Sea. Mar. Ecol. Prog. Ser. 63: 65-77

Lomstein, B. A., Blackburn, T. H., Henriksen, K. (1989). Aspects of nitrogen and carbon cycling in the northern Bering Shelf sediment. I. The significance of urea turnover in the mineralization of $\mathrm{NH}_{4}{ }^{+}$. Mar. Ecol. Prog. Ser. 57: $237-247$

Nixon, S. W (1981). Remineralization and nutrient cycling in coastal marine ecosystems. In: Neilson, B. J., Cronin, L. E. (eds.) Estuaries and nutrients. Humana Press, Clifton, NJ

Novitsky, J. A. (1990). Evidence for sedimenting particles as the origin of the microbial community in a coastal marine sediment. Mar. Ecol. Prog. Ser. 60: 161-167

Parsons, T. R., Maita, Y., Lalli, C. M. (1984). A manual of chemical and biological methods for seawater analysis. Pergamon Press, Oxford

Propp, M. V., Tarasoff, V. G., Cherbadfgi, I. I., Lootzik, N. V (1980). Benthic-pelagic oxygen and nutrient exchange in a coastal region of the Sea of Japan. In: Tenore, K. R., Coull, B. C. (eds.) Marine benthic dynamics. Univ. of South Carolina Press, Columbia, p. 265-284

This article was presented by G. C. Harding (Senior Editorial Advisor), Dartmouth, Nova Scotia, Canada
Rizzo, W. M. (1990). Nutrient exchanges between the water column and a subtidal benthic microalgal community. Estuaries 13: 219-226

Solarzano, L., Sharp, J. H. (1980a). Determination of total dissolved phosphorus and particulate phosphorus in natural waters. Limnol. Oceanogr. 25: 754-758

Solarzano, L., Sharp, J. H. (1980b). Determination of total dissolved nitrogen in natural waters. Limnol. Oceanogr. 25: $751-754$

Strass, V (1990). On the calibration of large-scale fluorometric chlorophyll measurements from towed undulating vehicles. Deep Sea Res. 37(3): 525-540

Stumm, W., Morgan, J. J. (1981). Aquatic chemistry. John Wiley and Sons, New York

Sundby, B., Gobeil, C., Silverberg, N., Mucci, A. (1992). The phosphorus cycle in coastal marine sediments. Limnol. Oceanogr. 37: 1129-1145

Tessier, A., Campbell, P., Bisson, M. (1979). Sequential extraction procedure for the speciation of particulate trace metals. Analyt. Chem. 51. 844-850

Van Kessel, J. F. (1977). Factors affecting the denitrification rate in two water sediment systems. Water Res. 11: $259-267$

Wilkinson, L., Hill, M., Miceli, S., Birkenbeuel, G., Vang, E. (1992). SYSTAT for Windows: Graphics, Version 5 edn. SYSTAT Inc., Evanston, IL.

Manuscript first received: November 13, 1993

Revised version accepted: July 20,1994 